\title{
Evaluation of The Implementation of Occupational Health and Safety Programs in Logistics Companies in Pekanbaru
}

\author{
${ }^{1}$ Endang Purnawati Rahayu, ${ }^{2}$ Herniwanti \\ Public Health Master Study Program, STIKes Hang Tuah Pekanbaru \\ Jl. Mustafa Sari No.5 Tangkerang Selatan, Bukit Raya, Pekanbaru, Riau 28281 \\ E-mail: endangpurnawati90@gmail.com
}

\begin{abstract}
Implementation of occupational safety and health programs to guarantee safety and health for workers spiritually and physically while doing work. In every activity or activity, accidents may occur that claim lives and property, one of which is loading and unloading activities which have risks in each activity process. This study aims to evaluate the implementation of occupational safety and health programs in loading and unloading companies. This research is a qualitative descriptive study. The design of this research is survey research. Primary data were obtained through interviews and observations, while secondary data were obtained from company documents. The results showed that the implementation of the occupational safety and health program in this loading and unloading company was still lacking and did not comply with the applicable standards, namely human resources that did not meet standards, standard operating procedures that lacked socialization and supervision to workers, there was no safety training program and occupational health is following the type of work, the use and provision of personal protective equipment are still lacking and hazard control has been carried out, but it is necessary to carry out supervision when loading and unloading work is carried out.
\end{abstract}

Keywords: Occupational safety and Health programs 


\section{INTRODUCTION}

Implementation of occupational safety and health programs to guarantee safety and health for workers spiritually and physically while doing work. The existence of this occupational safety and health program can increase work motivation and employee performance which affects reducing the number of accidents in the workplace (Dewi, 2014). In addition, the implementation of occupational safety and health programs and the presence of high work motivation from workers can increase employee work productivity (Maiti and Bidinger, 1981)

According to the Work Safety Law No.1 of 1970 that the government strives to tackle occupational safety and health issues concerning both institutional legislation, supervision, and law enforcement rules. Including one of the implementations of occupational safety and health programs in the workplace which is an absolute matter to be carried out in a business for the production of goods and services (UU RI Nomor 1 Tahun 1970, 1970)

According to the International Labor Organization (ILO) in 2018, every year around 380,000 workers, or 13.7 percent of the 2.78 million workers who die from work accidents, one of the causes is the low awareness of employers and employees about the importance of implementing OSH. Accidents that occurred in Indonesia in 2018 were 173,105 cases, in 2019 there were 77,295 cases. And the accidents that occurred in Riau Province were 14,325 cases (BPJS Ketenagakerjaan, 2020).

In every activity or activity, accidents can occur that claim lives and property. Accidents can occur to workers caused by negligence or high-risk work, such as working in mining, high-voltage electric currents, and others that can cause death and disability (Chandra, 2006).

Labor protection consists of several aspects, including safety, health, the morale of the workforce, and treatment and policies for workers following human dignity following their work. Loading and unloading labor is one of the jobs that have the risk of accidents when doing work so that the safety and security of workers when carrying out loading and unloading activities become a priority so it is advisable to wear all body safety equipment (Hasibuan, 2017). Loading and unloading workers often behave unsafely at a moderate level so that training is needed to increase knowledge about hazards and unsafe actions in the workplace, especially those aged 31-40 years and have an elementary education (Suryanto and Widajati, 2017)

Several risk factors can occur in loading and unloading work, including hazards in each work process, the danger in the work process that stevedoring can be hit by goods, the work process of a car going the position of the body bending when lifting goods and the process delivery can fall from a height when stacking the goods above trucks (Saragih, 2012), from the process of placing the crane to directing the truck to leave the dock 14 potential hazards can occur, namely 3 hazard sources with extreme categories, 9 hazard sources with high-risk categories and 2 hazard sources with medium risk categories (Muhamid, Tambunan and Fatimahhayati, 2018). From this, several factors need special 
attention in implementing occupational safety and health programs in the workplace. One of them is human resources who are an important part and asset in a company, so companies are required to manage human resources effectively and efficiently to increase work productivity which is marked by a decrease in the number of occupational accidents and occupational diseases (Dewi, 2014). Companies need to carry out occupational safety and health training following the characteristics and needs of each job to increase workers' knowledge and skills in implementing occupational safety and health programs (Yulius and Lubis, 2019).

In the loading and unloading work process it is also necessary to control by providing personal protective equipment for workers besides that it is also necessary to carry out occupational safety and health training to increase awareness of the importance of using personal protective equipment because many accidents occur as a result of worker negligence by ignoring the importance of using personal protective equipment (Hasibuan, 2017).

Based on the preliminary survey in loading and unloading companies related to the implementation of occupational safety and health programs, there are several problems, including the work safety and health program that has not been running optimally in the company which is marked by a lack of concern and knowledge of workers to wear personal protective equipment, safety training, and occupational health is only limited to socialization to workers, and there have been cases of accidents in the workplace. The problems mentioned above, of course, will affect the comfort and safety of workers when doing work so that it will affect work productivity. Therefore, this study aims to evaluate the implementation of occupational safety and health programs that have not been running optimally to increase efficiency and effectiveness in doing work.

\section{METHODS}

This research is a qualitative descriptive study. The design of this research is survey research by describing what is happening or is in the loading and unloading company. The subjects of this study consisted of two crane operators, two forklift operators, company directors, loading masters, and manager representatives. The research data was taken from the results of in-depth interviews, literature studies, and direct observations in the company by researchers conducted from June to August 2020. The primary data of this study were taken directly from informants in the loading and unloading company using interview guidelines and observation results with checklists, while secondary data were taken from literature studies. The data that has been obtained by the researcher is then analyzed by several stages, namely data reduction, data presentation, and conclusion drawing. After analyzing the data to maintain the validation of the data collected by the researcher, triangulation was carried out using the triangulation of sources and methods. This study has received ethical clearance from the Hang Tuah Institute of Health Science, Pekanbaru number 325.a/KEPK/STIKes-HTP/VI/2020 to protect the rights and health and secrecy of medical studies. 


\section{RESULTS AND DISCUSSION}

Resources in loading and unloading companies are still lacking and do not meet standards, with several findings such as the triangulation matrix below:

Table 1. Human Resource Triangulation Matrix

\begin{tabular}{|c|c|c|c|}
\hline $\begin{array}{c}\text { In-depth } \\
\text { Interview } \\
\end{array}$ & Observation & $\begin{array}{c}\text { Document } \\
\text { Review }\end{array}$ & Conclusion \\
\hline $\begin{array}{l}\text { Average worker education } \\
\text { in Secondary School }\end{array}$ & - & $\begin{array}{l}\text { Photocopy of workers } \\
\text { certificates }\end{array}$ & \multirow{4}{*}{$\begin{array}{l}\text { Workers in loading and } \\
\text { unloading companies do } \\
\text { not meet applicable } \\
\text { standards }\end{array}$} \\
\hline $\begin{array}{l}\text { The number of loading } \\
\text { and unloading personnel } \\
\text { is not following the rules }\end{array}$ & $\begin{array}{l}\text { Workers are few but } \\
\text { the work is done a lot }\end{array}$ & $\begin{array}{l}\text { Not Following loading } \\
\text { and unloading rules }\end{array}$ & \\
\hline Lack of field supervision & $\begin{array}{l}\text { During loading and } \\
\text { unloading, there are no } \\
\text { supervisors }\end{array}$ & - & \\
\hline $\begin{array}{l}\text { Crane operators do not } \\
\text { have K3 licenses }\end{array}$ & $\begin{array}{l}\text { Operators do not have } \\
\text { workbooks }\end{array}$ & $\begin{array}{l}\text { Do not have certificates } \\
\text { and workbooks }\end{array}$ & \\
\hline
\end{tabular}

Based on table 1, shows that in terms of education, the average worker in the loading and unloading company has a high school diploma, seen from a large number of workers in the loading and unloading company that the number of loading and unloading workers must match the number of loading and unloading workers in one team, but in reality, the number of workers is insufficient and does not match the number of loading and unloading workers in one team. And the loading and unloading supervision personnel are also lacking so that when the loading and unloading work is carried out there are no supervisors in the field. And also crane operators who do not have a work safety and health license are found because they have never participated in a competency certification according to their type and qualifications. This condition is very risky for operators crane who do not have a work safety and health license because to operate a crane one of the conditions is that it has passed the operator test which is carried out by the Director General's document inspection team with the classification of the average working period of workers who have worked more than 1 (one) year. So that the human resources in this loading and unloading company need an increase in both the number needed and the increase in the qualification of training that is attended by workers.

Loading and unloading companies have standard operating procedures, but there are still some findings related to standard operating procedures, such as the triangulation matrix below:

Table 2. Triangulation Matrix of Standard Operating Procedures

\begin{tabular}{|c|c|c|c|}
\hline $\begin{array}{c}\text { In-depth } \\
\text { interview }\end{array}$ & Observation & Document review & Conclusion \\
\hline $\begin{array}{l}\text { Standard operating } \\
\text { procedures are available }\end{array}$ & $\begin{array}{l}\text { No operational } \\
\text { standards are found } \\
\text { attached to work areas }\end{array}$ & $\begin{array}{l}\text { Found } \quad \text { standard } \\
\text { operating } \quad \text { procedures } \\
\text { filed by companies }\end{array}$ & $\begin{array}{lr}\text { Standard } & \text { operating } \\
\text { procedures in loading } \\
\text { and }\end{array}$ \\
\hline $\begin{array}{l}\text { Some workers do work } \\
\text { that is not following }\end{array}$ & $\begin{array}{l}\text { Found workers who do } \\
\text { not use personal }\end{array}$ & $\begin{array}{l}\text { Some files on worker } \\
\text { administrative sanctions }\end{array}$ & $\begin{array}{l}\text { companies need to be } \\
\text { disseminated }\end{array}$ \\
\hline
\end{tabular}




\begin{tabular}{|c|c|c|c|}
\hline $\begin{array}{l}\text { In-depth } \\
\text { interview }\end{array}$ & Observation & Document review & Conclusion \\
\hline $\begin{array}{ll}\text { standard } & \text { operating } \\
\text { procedures } & \\
\end{array}$ & protective equipment & & \multirow{2}{*}{$\begin{array}{l}\text { supervised to workers } \\
\text { regarding risks that can } \\
\text { be Occurs while doing } \\
\text { work }\end{array}$} \\
\hline $\begin{array}{l}\text { Lack of supervision } \\
\text { during work }\end{array}$ & $\begin{array}{l}\text { No supervisors are } \\
\text { found when the work } \\
\text { is carried out }\end{array}$ & - & \\
\hline
\end{tabular}

Based on table 2, shows that the company already has standard operating procedures for work processes but these standard operating procedures are not posted in the work area so that workers cannot read or just remind the correct standard operating procedures when doing work so that workers who do not follow standard operating procedures while performing work. Moreover, there is a lot of loading and unloading work that must be completed in a short time, so many workers do not follow the existing standard operating procedures, this should be a special concern for workers considering the dangers and risks that can occur when doing work. And the lack of supervision in the field also has an impact on the negligence of workers who feel that they are not being supervised while doing their work.

Training The training carried out in loading and unloading companies is still lacking so that some findings areas in the triangulation matrix below:

Table 3. Matrix of Reduction of Occupational Safety and Health Training

\begin{tabular}{|c|c|c|c|}
\hline $\begin{array}{l}\text { In-depth } \\
\text { interview }\end{array}$ & Observation & Document review & Conclusion \\
\hline $\begin{array}{l}\text { Some workers have not } \\
\text { attended training according to } \\
\text { the type of work }\end{array}$ & $\begin{array}{l}\text { Some workers do not } \\
\text { have a }\end{array}$ & $\begin{array}{l}\text { certificate. The } \\
\text { worker's certificate is } \\
\text { incomplete. }\end{array}$ & \multirow{5}{*}{$\begin{array}{l}\text { Occupational safety and } \\
\text { health training is still } \\
\text { lacking so it is necessary } \\
\text { to hold regular training } \\
\text { programs in the } \\
\text { companies of }\end{array}$} \\
\hline $\begin{array}{l}\text { workers who have attended } \\
\text { training but } \\
\text { implementation has been a } \\
\text { long time ago }\end{array}$ & $\begin{array}{l}\text { Workers have a } \\
\text { certificate The }\end{array}$ & $\begin{array}{l}\text { a certificate is held for } \\
\text { more than } 10 \text { years }\end{array}$ & \\
\hline $\begin{array}{l}\text { the company only conducts } \\
\text { informal counseling }\end{array}$ & $\begin{array}{l}\text { Only provides } \\
\text { information } \begin{array}{r}\text { through } \\
\text { safety briefings }\end{array} \\
\end{array}$ & $\begin{array}{l}\text { No structured training } \\
\text { documentation is } \\
\text { found The }\end{array}$ & \\
\hline $\begin{array}{l}\text { company does not have a } \\
\text { regular training program }\end{array}$ & - & $\begin{array}{l}\text { Does not have a } \\
\text { training program for } \\
\text { employees }\end{array}$ & \\
\hline $\begin{array}{l}\text { the company participates } \\
\text { participating in invitations } \\
\text { related to training conducted } \\
\text { by government or private } \\
\text { agencies. }\end{array}$ & training documentation & Photo During training & \\
\hline
\end{tabular}

Based on table 3, shows that it is found that workers have never attended training according to their type of work, and many workers have attended training for a long time so it is necessary to carry out regular training for workers to increase workers' knowledge. This is also supported by the results of observations and document review that many of the certificates held by workers were more than 10 years ago. So far, the company has conducted informal safety and health training by 
providing counseling to workers during monitoring or safety briefings and there is no specific time for companies to carry out programmed occupational safety and health training from the company. So far the company has only relied on its workers to attend occupational safety and health training held by the Riau Province Dinas Tenaga Kerja dan Transmigrasi or other private agencies by sending worker representatives to attend training. In response to this, companies need to hold regular work safety and health training for workers to increase workers' knowledge.

Equipment in loading and unloading companies is still lacking as indicated by several findings in the triangulation matrix below:

Table 4. Triangulation Matrix of Personal Protective Equipment

\begin{tabular}{|c|c|c|c|}
\hline $\begin{array}{l}\text { In-depth } \\
\text { interview }\end{array}$ & Observation & Document review & Conclusion \\
\hline $\begin{array}{l}\text { Some workers do not use } \\
\text { personal } \\
\text { equipment }\end{array}$ & $\begin{array}{l}\text { It is found that } \\
\text { workers do not use } \\
\text { personal protective } \\
\text { equipment }\end{array}$ & $\begin{array}{l}\text { Warning letter/sanction is } \\
\text { found for workers who do } \\
\text { not use personal protective } \\
\text { equipment The use of } \\
\text { personal protective }\end{array}$ & $\begin{array}{l}\text { Equipment is still low in } \\
\text { loading and unloading } \\
\text { companies }\end{array}$ \\
\hline $\begin{array}{l}\text { Some of the personal } \\
\text { protective } \\
\text { provided is incomplete }\end{array}$ & $\begin{array}{l}\text { the condition of } \\
\text { personal protective } \\
\text { equipment } \\
\text { damaged }\end{array}$ & $\begin{array}{l}\text { Data on the number of } \\
\text { personal } \\
\text { equipment }\end{array}$ & \\
\hline $\begin{array}{l}\text { The company provides } \\
\text { sanctions for workers who } \\
\text { do not use personal } \\
\text { protective equipment }\end{array}$ & - & $\begin{array}{l}\text { A warning letter from the } \\
\text { company for workers }\end{array}$ & \\
\hline
\end{tabular}

Based on table 4, shows that the use of personal protective equipment is still low, which is indicated by workers who do not use personal protective equipment when doing work, this condition is very risky for workers who do work not using personal protective equipment. And in response to this condition, the company has implemented administrative sanctions in the form of a warning letter for workers who do not use personal protective equipment. However, the results of field observations found that there was some personal protective equipment that was incomplete and damaged conditions were found in the field, as in the following table:

Table 5. Observations on the Condition of Personal Protective Equipment

\begin{tabular}{|c|c|c|c|c|}
\hline \multirow{2}{*}{$\begin{array}{c}\text { Type of Personal } \\
\text { Protective Equipment }\end{array}$} & \multicolumn{2}{|c|}{ Availability } & \multicolumn{2}{|c|}{ Condition } \\
\hline & Yes & Not & Good & Not \\
\hline Head Protection Equipment & $\sqrt{ }$ & & $\sqrt{ }$ & \\
\hline Face Protection & $\sqrt{ }$ & & & $\sqrt{ }$ \\
\hline Ear protection device & & $\sqrt{ }$ & & - \\
\hline Mask & $\sqrt{ }$ & & $\sqrt{ }$ & \\
\hline Hand Protective Equipment & $\sqrt{ }$ & & $\sqrt{ }$ & \\
\hline Foot Protection Equipment & $\sqrt{ }$ & & & $\sqrt{ }$ \\
\hline Protective Clothing & $\sqrt{ }$ & & $\sqrt{ }$ & \\
\hline Safety Strap & & $\sqrt{ }$ & & - \\
\hline
\end{tabular}


From table 5, it shows that of the 8 types of personal protective equipment available, 6 types of protective equipment are available in the company, namely head protection, face protection, masks, hand protective equipment, foot protective equipment, and protective clothing. However, there is personal protective equipment available that is in good condition and not so this may be one of the reasons for workers not using personal protective equipment other than the reason for workers feeling uncomfortable when using personal protective equipment. And what the other 2 types of personal protective equipment that are not available are ear protection and safety straps.

Control carried out by loading and unloading companies is good enough as in the triangulation matrix below:

Table 6. Hazard Control Triangulation Matrix

\begin{tabular}{llll}
\hline \multicolumn{1}{c}{$\begin{array}{c}\text { In-depth } \\
\text { interview }\end{array}$} & \multicolumn{1}{c}{ Observation } & Document review & Conclusion \\
\hline Administrative controls & $\begin{array}{l}\text { Found several } \\
\text { documents }\end{array}$ & $\begin{array}{l}\text { The existence of } \\
\text { standard operational } \\
\text { procedures }\end{array}$ & $\begin{array}{l}\text { Hazard control carried } \\
\text { out by loading and } \\
\text { unloading companies is } \\
\text { good enough }\end{array}$ \\
$\begin{array}{llll}\text { Engineering engineering } \\
\text { control }\end{array}$ & $\begin{array}{l}\text { System sterile area at } \\
\text { least 150 m from the } \\
\text { workplace and install a } \\
\text { wind speed detector }\end{array}$ & \\
$\begin{array}{l}\text { Control of the use of } \\
\text { personal protective } \\
\text { equipment }\end{array}$ & $\begin{array}{l}\text { There were still } \\
\text { workers who did not } \\
\text { use personal protective } \\
\text { equipment }\end{array}$ & $\begin{array}{l}\text { Standard operational } \\
\text { procedures for the use of } \\
\text { personal protective } \\
\text { equipment existed }\end{array}$ & \\
\hline
\end{tabular}

From table 6, it shows that the hazard control carried out by the loading and unloading company is quite good, this is seen from several hierarchies of control that have been carried out by the company to control hazards in the workplace. Some of the controls that have been carried out by the company are administrative control, namely the availability of standard operating procedures related to hazard control in the workplace, engineering controls, namely the company has made a system of sterile areas to carry out loading and unloading activities and installing tools to measure wind speed, as well as controlling use. Personal protective equipment, namely the company has standard operating procedures for using personal protective equipment, but during implementation, there were still found workers who did not use personal protective equipment due to workers' lack of knowledge of work risks and lack of supervision in the workplace.

Human resources in loading and unloading companies have not met the applicable standards, from the many findings that exist in the field that this condition greatly affects the quality and performance of human resources in a company. The role of human resources is very decisive for the realization of organizational goals, therefore it requires a workforce who is capable, skilled, and has the desire to work effectively and efficiently. 
Loading and unloading workers are all workers registered at the local port who carry out loading and unloading work at the port. According to the (Keputusan Menteri Perhubungan, no date) loading and unloading, workers are all workers registered at the local port who carry out loading and unloading work at the port. So that the loading and unloading power is one of the most important factors in carrying out loading and unloading activities at the port.

The development of port human resources is directed at empowering human resources, especially in the quality and quantity of the existing workforce, in anticipation of increasingly complex service requests or from customers or partners, so that specific or special services are needed for port services (Pelindo, 2000). In this case, human resources as seen from the level of knowledge of employees in carrying out loading and unloading activities will have a direct effect on the quantity and quality of work output. Panhandle employees must know the various equipment used in loading and unloading activities, as well as the stages of activities in carrying out loading and unloading activities, as well as knowledge of the use of occupational safety and health equipment while working. This is done to maintain safety while doing work (Hadiguna and Sari, 2015)

Indonesia has a relatively moderate quality of human resources, so the high and low quality will determine the productivity of Indonesia's workforce. Currently, Indonesia's labor productivity is in 4th place (relatively moderate) at the ASEAN level and 11th out of 20 member countries of the Asian Productivity Organization (APO) (Hartoto, 2019). The development of the quality of national human resources can be done by implementing an education system that is more focused on certain fields. One thing that can be done for human resource development is that loading and unloading workers take Occupational Health and Safety training to get a license OHS as one of the requirements that crane operators must have (Ricardianto et al., 2020).

According to the Regulation of the Minister of Manpower and Transmigration of the Republic of Indonesia number PER.09/MEN/VII/2010 concerning operators and officers of lift and transport aircraft. To become an operator and officer of lift and transport aircraft, some requirements need to be met by every worker, including having a minimum high school education, having a K3 license and workbook, having work experience following the operator class classification for at least 1 year (Tenaga, Dan, and Republik, 2010). In terms of the number of human resources, the regulations and policies do not determine the number of workers who must be in the loading and unloading company, but the number of operators employed by the company must have the qualifications and numbers that match the type and capacity of lift and transport aircraft. This is not following the conditions in the company because there are still operators who do not have K3 licenses and workbooks and the amount of supervision is still insufficient because the results of observations found that there were many and many goods that had to be unloaded in a short time and needed accuracy and caution in doing work. So that it is necessary to increase the amount of supervision 
following a large number of loading and unloading goods in the company. This is an important reference that operators must have a $\mathrm{K} 3$ license and the company must facilitate workers to obtain the K3 license, and this is an obligation for the company to meet the requirements determined by government policy so that all operators and workers in The loading and unloading company already has a $\mathrm{K} 3$ license and $\mathrm{K} 3$ training which is required for loading and unloading companies.

In the Decree of the Minister of Transportation (2014) it explains that a large number of workers and supervision in each loading and unloading activity in a group, however, the condition of this loading and unloading company is that there is a lack of supervisory personnel so that supervisors are rarely supervised in the field supervision process, and this condition making workers negligent, which is one reason workers pay less attention to the situation and risks that will occur while doing work. The level of work achievement of employees in loading and unloading activities in connection with the planning and supervision carried out. Because ineffective planning and supervision will result in constraints including frequent delays resulting in a lot of time being wasted without doing work so that the throughput Pieris also low, the utilization of dock resources is low and low the throughput is a ship which can lead to longer ships. is at the port and this causes a decrease in work productivity.

As the demolition company already has standard operating procedures, standard operating procedures are guidelines used to ensure that the organization's or company's activities run smoothly (Sailendra, 2015). A good standard operating procedure can be a reference and guide for carrying out work, facilitate supervision and improve good coordination between divisions within a company. So that every job done requires standard operating procedures and this becomes important for carrying out the duties and functions of every element or unit of the company.

If there are still some workers who do work that is not following standard operating procedures, then this condition may be a lack of knowledge of workers' knowledge of the importance of standard operating procedures as a guide for doing work so that unwanted things do not occur due to loading and unloading hazards that can cause accidents during the process. work takes place if the worker does not follow standard operating procedures. According to (Alvernia, S.P., Kurniawan, B. Lestantyo, 2018), standard operating procedures are needed in the operation of transportation equipment in doing work so that workers can work safely and comfortably.

This condition needs special attention for companies to anticipate or increase workers' understanding of the importance of working following standard operating procedures set by the company. The role of standard operating procedures is increasingly needed by companies as a guide in carrying out a work process. Standard Operating Procedures can streamline and streamline every series of activities of officers in the field. Like the Surabaya Container Terminal Company in the process of serving container acceptance, container loading, container unloading, container discharge, 
it is hoped that it can make it easier for container terminal users to meet their needs so that the need for standard operating procedures is socialized to all workers so that all work can be carried out according to standards existing operational procedures (Somadi, 2020).

In addition, in the work process, it is necessary to carry out strict supervision to support the work process so that it runs well and is following applicable standard operating procedures. The amount of work done by workers such as arranging container stacking patterns following standard operating procedures and supervision is carried out properly so that it can improve container loading and unloading operational performance (Handajani, 2004). There are no supervisors found in the field so that it is not following the Decree of the Minister of Transportation (2014) which requires supervision in the field during the work process to carry out supervision, including following standard operating procedures when doing work. The need to follow standard operating procedures that already exist in the company when carrying out the operation of conveyances in carrying out work so that workers can work safely and avoid the risks that will occur due to work that is not following standard operating procedures (Alvernia, S.P., Kurniawan, B. Lestantyo, 2018). So that this condition needs to be closely monitored by the company in the process of implementing the work carried out by the workers.

At dismantling companies that some workers have not attended training according to the type of work, education and training is an effort to equip knowledge, skills, and attitudes of people to improve abilities and achieve individual and organizational goals at present and in the future. (Hadi, 2014). So that training is important for someone to follow to increase self-confidence and ability to do work. The specification of occupational safety and health training is an activity where workers acquire knowledge of the dangers of work accidents, acquire new skills, educate workers to face potential hazards so that workers have a safe work attitude and care about safety conditions in the workplace and can maintain safe behavior. in their work environment in general, both at work and in workshops / outside the environment (Kurnia, 2010).

The implementation of this occupational safety and health training can improve worker performance and has a very significant effect on the job training on the performance of the loading and unloading employees at the Long Branch Container Terminal (NELSON, 2012). Because training is one of the factors needed by employees to carry out work properly related to work safety. The existence of safety training provided by the company will make employees work more cautiously and can protect themselves from workplace accidents that may occur (Lestari, 2017).

Companies must carry out regular training bearing in mind that training carried out routinely by the company can provide provisions for workplace personnel to implement occupational safety and health so that workers understand and behave safely, can identify hazards in the workplace, and prevent work accidents so that workers can work safely and for as long (Hargiyarto, 2010). 
Human resource competence is very important in an organization. Competence aims to provide direction to companies in recruiting employees, placing employees, and providing training for employees. Broadly speaking, a standard of competence as a port operator in a port is needed, because the port is the center of economic activity which is not only visited by domestic ships but also ships from other countries. So it is necessary to assign employees according to their abilities so that the goals of each division can be achieved to achieve organizational goals (Hadiguna and Sari, 2015).

The safety and health training provided by the company is still lacking, even though the company has participated in participating in training held by other agencies, this is not sufficient to increase workers' knowledge because not all workers have attended the training. This needs to be done to increase knowledge through regular training. So in this case the company needs to carry out training following the type of work that is in the workplace and can be scheduled regularly and in a structured manner so that it is included in one of the K3 programs that are carried out in the workplace.

In loading and unloading companies it was found that some workers did not use personal protective equipment, even though personal protective equipment was a set of tools used by workers to protect all or part of their body against the possibility of potential hazards in the workplace or work accidents. Personal protective equipment is a tool that must be used when working according to work hazards and risks to maintain the safety of the workforce itself and also others around them (Kurniawati, 2013).

The criteria for the highest cause of accidents is the human factor who does not use personal protective equipment while doing work (about 56\%) (Sepang et.al (2013), and the use of personal protective equipment greatly affects workers' behavior to implement occupational safety and health (Wahyu, 2014) ). So in Act No. 1 of 1970 on occupational safety has ruled that the obligation of leadership workplaces and workers to implement workplace safety one of them to wear personal protective equipment that is required. So the company has to provide personal protective equipment that is complete and in condition good for workers and workers must use personal protective equipment following the types and risks that exist in the workplace.

Companies are required to determine personal protective equipment that must be used to protect workers and have an obligation to provide personal protective equipment, including personal protective equipment. bad for the eyes, face, head, and feet, as well as protective clothing and barriers. Companies must also ensure that their workers use and maintain personal protective equipment in sterile and reliable conditions (Kurniawati, 2013).

So that companies also must provide personal protective equipment for workers following the work and personal protective equipment is always in good condition and replaced at least every 6 
months if there is damage to personal protective equipment. If the company has provided suitable personal protective equipment, workers are obliged to use personal protective equipment and no worker does not want to use personal protective equipment because it is not provided by the company, feels uncomfortable, and others. And in this condition, it is necessary to conduct socialization or training related to the use of personal protective equipment to workers that this personal protective equipment is needed to protect workers while doing work and reduce accidents and occupational diseases. In addition, it is also necessary to provide strict sanctions for workers who do not use personal protective equipment while working.

Loading and unloading companies have taken several steps to control hazards. Hazards are all sources, situations, or activities that have the potential to cause injury (work accidents) and/or occupational diseases (Bacchetta, 2007) And according to Adzim (2013), there are five types of K3 hazards in the workplace, namely: biological, chemical, physical/mechanical, biomechanical and social psychological hazards. The number of hazards that can occur in the workplace can create risks that can occur for workers or the workplace environment. So it is necessary to control hazards to minimize the risks that can occur in the workplace. Some of the steps that have been taken by loading and unloading companies are administrative control with the existence of standard operating procedures in the company as a reference for all workers to carry out their work, engineering control by installing sterile areas during loading and unloading so that no other workers enter the loading area. loading and by installing wind speed detection devices to estimate wind speed conditions that can interfere with the loading and unloading process, and controlling personal protective equipment by providing personal protective equipment worn by workers when doing work.

As is done by PT Pelindo III Banjarmasin branch to control hazards when carrying out loading and unloading activities, including during bad weather to minimize the risk of damage to goods during loading and unloading, adding loading and unloading tools in addition to alternative routine maintenance of loading and unloading equipment, expanding land for stacking goods or container yards, conducts training or training for loading and unloading workers for provision and development of the capacity of each loading and unloading workforce (Nurdiana, 2020).

Several risks can occur when loading and unloading work in each work process. From low to high-risk categories during the stevedoring, cargo during, and delivery processes. So that companies need to anticipate risks that can occur in the workplace by implementing hazard controls that can minimize the hazards that will occur following the hazard control hierarchy (Saragih, 2012).

From other research, the controls carried out at the Karya Business Cooperative and PT Pelabuhan Indonesia III (PERSERO) Tanjung Perak Branch are technical control, administrative control, and personal protective equipment (PPE). The dangers of loading and unloading work with cranes have been made to control efforts to the ALARP (stages Low As Possible Reasonably 
Practicable). The Karya Business Cooperative and PT Pelabuhan Indonesia III (PERSERO) Tanjung Perak Branch need to carry out training related to loading and unloading containers with cranes periodically for each loading and unloading workforce (Senjayani and Martiana, 2019)

Types of hazard control are divided into 5 (five) parts, including elimination by eliminating sources of danger, substitution by replacing sources of hazards with those with low risk, engineering by using tools or designing tools to reduce hazards, administration with administrative policies such as shifts work, workplace rotation, standard operating procedures, and others, finally with the use of personal protective equipment following the hazards in the workplace (Ramli, 2010). So the company has implemented 3 (three) hazard control out of 5 existing hazard control steps.

In exercising control, what must be done is to start from the biggest action, if it cannot be done then reduce the level of control that is lower / easier (Suardi, 2007). So that in the process of controlling this hazard, it can be improved for the implementation of hazard control to reduce work accidents that occur in the workplace.

\section{CONCLUSION AND SUGGESTIONS}

The implementation of occupational safety and health programs in loading and unloading companies is still lacking and does not meet standards. This can be seen from several findings of occupational safety and health programs that are still lacking, such as human resources that do not meet standards because some workers do not have an occupational safety and health license and the number of workers is still insufficient, lack of socialization of standard operating procedures in the company and Supervision when doing work, it is necessary to carry out a training program on occupational safety and health regularly and workers must take special training according to the type of work, and there is a lack of socialization of the use of personal protective equipment and the provision of protective equipment that is complete and in good condition, and the control of hazards carried out it is good but it needs to be supervised while the loading and unloading work is being carried out.

\section{REFERENCES}

Alvernia, S.P., Kurniawan, B. Lestantyo, D. (2018) 'Analisis Faktor-Faktor Yang Mempengaruhi Keselamatan Pengoperasian Alat Angkat Bongkar Muat Peti Kemas (Studi Kasus di PT. Pelabuhan Tanjung Priok)', Jurnal Kesehatan Masyarakat (e-Journal), 6(4), pp. 353-360.

Bacchetta, A. P. (2007) '[B-BS and occupational health and safety management systems].', Giornale italiano di medicina del lavoro ed ergonomia, 32(1 Suppl A), pp. A55-8. Available at: http://www.ncbi.nlm.nih.gov/pubmed/20518211.

Dewi, I. (2014) 'Pengaruh Program Keselamatan Dan Kesehatan Kerja Terhadap Motivasi Dan Kinerja Karyawan (Studi pada Karyawan PT. YTL Jawa Timur)', Jurnal Administrasi Bisnis 
S1 Universitas Brawijaya, 16(1), p. 84897.

Hadiguna, R. A. and Sari, R. Y. (2015) 'Kompetensi Sumber Daya Manusia untuk Logistik Pelabuhan di PT Pelindo II Cabang Teluk Bayur', Academia.Edu, (June). doi: 10.13140/RG.2.2.12578.84164.

Handajani, M. (2004) 'Analisis Kinerja Operasional Bongkar Muat Peti Kemas Pelabuhan Tanjung Emas Semarang', Jurnal Transportasi Jurnal Transportasi Juni, 4(1), pp. 1-12.

Hasibuan, D. K. (2017) 'Implementasi Program Kesehatan dan Keselamatan Kerja (K3) Kepada Tenaga Kerja Bongkar Muat yang Berada di Koperasi Samudra Sejahtera (KOMURA) ...', Jurnal Universitas Mulawarman, 2(1), pp. 1-11. Available at: http://perpustakaan.unmul.ac.id/ejournal/index.php/um/article/view/138.

Keputusan Menteri Perhubungan (no date) 'Km_No_14_Tahun_2002.Pdf'.

Lestari (2017) 'Hubungan Keselamatan Dan Kesehatan Kerja (K3) Terhadap Kinerja Karyawan Pt. Haleyora Powerindo Pekanbaru', Jom Fisip, 3(2), pp. 399-404.

Maiti and Bidinger (1981), Journal of Chemical Information and Modeling, 53(9), pp. 1689-1699.

Muhamid, R., Tambunan, W. and Fatimahhayati, L. D. (2018) 'Analisis Risiko Keselamatan dan Kesehatan Kerja Kegiatan Bongkar Muat Pupuk', Jurnal INTECH Teknik Industri Universitas Serang Raya, 4(2), p. 45. doi: 10.30656/intech.v4i2.924.

Nelson, N. (2012) 'Pengaruh Pelatihan Kerja Terhadap Kinerja Karyawan Bagian Bongkar Muat Barang Di Terminal Peti Kemas Cabang Panjang', Jurnal Manajemen dan Bisnis Universitas Bandar Lampung, 3(1), p. 111359.

Ramli, S. (2010) 'Sistem Manajemen Keselamatan \& Kesehatan Kerja', Dian Rakyat, Jakarta.

Ricardianto, P. et al. (2020) 'Peluang dan Tantangan Sumber Daya Manusia dalam Penyelenggaraan Pelabuhan Cerdas (Smart Port) Nasional di Masa Revolusi Industri 4.0', Warta Penelitian Perhubungan, 32(1), pp. 59-66. doi: 10.25104/warlit.v32i1.1524.

Saragih, W. . (2012) 'Penilaian Risiko Kecelakaan Kerja Pada Tenaga Kerja Bongkar Muat Di Pelabuhan Teluk Nibung Tanjung Balai Asahan Tahun 2015', 50(February), pp. 3-10. Available at: file:///F:/ali/payanname/Article/ pdf.

Senjayani, S. and Martiana, T. (2019) 'Penilaian Dan Pengendalian Risiko Pada Pekerjaan Bongkar Muat Peti Kemas Oleh Tenaga Kerja Bongkar Muat Dengan Crane', Journal of Public Health Research and Community Health Development, 1(2), p. 120. doi: 10.20473/jphrecode.v1i2.16244.

Suryanto, D. I. D. and Widajati, N. (2017) 'Hubungan Karakteristik Individu Dan Pengawasan K3 Dengan Unsafe Action Tenaga Kerja Bongkar Muat', The Indonesian Journal of Public Health, 12(1), p. 51. doi: 10.20473/ijph.v12i1.2017.51-63.

Tenaga, M., Dan, K. and Republik, T. (2010) 'Menteri tenaga kerja dan transmigrasi republik 
indonesia', pp. 1-13.

UU RI Nomor 1 Tahun 1970 'Undang-undang Republik Indonesia Nomor 1 Tahun 1970 Tentang Keselamatan Kerja', Ann. Rep. vet. Lab. N. England Zool. Soc. Chester Zool. Gardens, 1970(5), p. unpaginated.

Yulius, I. T. and Lubis, S. R. H. (2019) 'Gambaran Pelaksanaan Program Promosi K3 Pada Pt Pertamina Trans Kontinental Jakarta Tahun 2018', JUMANTIK (Jurnal Ilmiah Penelitian Kesehatan), 4(1), p. 15. doi: 10.30829/jumantik.v4i1.4035. 
Volume I Tahun 2021

November 2021
E-ISSN: 2808-5361

http://e-journal.fkmumj.ac.id/
Proceeding The First Muhammadiyah InternasionalPublic Health and Medicine Conference 